Article

\title{
The Climate Change Vulnerability and Risk Management Matrix for the Coastal Zone of The Gambia
}

\author{
Joshua Amuzu 1,* (D), Bubu P. Jallow 2 (D), Amos T. Kabo-Bah ${ }^{3}$ iD and Sidat Yaffa 4 \\ 1 West African Science Service Center on Climate Change and Adapted Land Use (WASCAL) Headquarters, \\ CSIR Office Complex, Airport Residential Area, P.M.B CT 504, Cantonments-Accra 0233, Republic of Ghana \\ 2 Department of Water Resources, 7, Marina Parade, Banjul, Republic of Gambia; bubudado.bpj@gmail.com \\ 3 Department of Energy and Environmental Engineering, University of Energy and Natural Resources, \\ P.O. Box 214, Sunyani, Republic of Ghana; amos.kabobah@uenr.edu.gh \\ 4 University of The Gambia, Farafenni Campus, North Bank Region, Republic of Gambia; syaffa@utg.edu.gm \\ * Correspondence: joshua.amuzu@yahoo.com; Tel.: +233-543-121-834
}

Received: 12 December 2017; Accepted: 30 January 2018; Published: 6 February 2018

\begin{abstract}
Global Climate Change is one of the dire challenges facing the international community today. Coastal zones are vulnerable to its impacts. An effective approach with long-term prospects in addressing climate change impacts is it's mainstreaming into development agenda of sectoral policies. A comprehensive risk and vulnerability assessment is a pre-requisite to ensure that the right adaptive response is taken for effective integration into developmental plans. The objective of this study is to evaluate and prioritize risks, vulnerability and adaptation issues of current and anticipated impacts of climate change on the coastal zone of The Gambia. The study will also give a methodological contribution for assessing risks, vulnerability and adaptation from the sub-national to local levels. The relevance of this study will be to create a link between the sub-national and local levels in order to facilitate the integration and mainstreaming of climate change into sectoral and local policies for more climate-resilient communities. This will aid in the promotion of strategic investment of constrained developmental resources to actualize successfully dynamic coping strategies, elude 'maladaptation' and less compelling responsive measures. A purposive expert sampling technique was used in selecting respondents for the study. The findings of the study reveal that by the end of the 21st century, the climatic variables likely to have the highest impact on the coastal zone of The Gambia are 'increased flood severity' and 'increased temperature'. The coastal zone of The Gambia showed a high vulnerability to these climate change variables. The suggested adaptive response in addressing the impacts of increased flood intensity in the study area includes; improving regulations for restricting agriculture and livestock grazing activities to improve land cover; strengthening of early-warning systems, among others. The suggested adaptive response in addressing the increase in temperature includes: increase crop diversification and rotation to reduce total crop failure; switching to drought-tolerant crop and animal species, among others.
\end{abstract}

Keywords: coastal zone; climate change; climate variability; vulnerability assessment; adaptation; The Gambia

\section{Introduction}

Global Climate Change (CC) is one of the dire challenges facing the international community today. Coastal zones are highly vulnerable to its impacts in the delivery of profoundly profitable services like tourism, fisheries, transportation, recreation, and human settlements. This study describes Coastal Zones (CZ) as the interface between land and ocean, including shallow waters and low-lying shoreline ecosystems. 
The coastal zone homes approximately $25-80 \%$ of the total populace in each coastal state in West Africa [1]. Many countries along the coast have their national capitals in the coastal zone. The annual contributions from Agriculture and Tourism to GDP from the coastal zone is estimated to be US $\$ 130$ billion and US $\$ 7.3$ billion respectively in West Africa [1,2]. The number of tourist arrivals in Africa expanded from 53.4 million individuals in 2015 to 57.8 million individuals in 2016 of which the coastal zone was the key tourism areas visited [3]. Tourism is the second largest contributor to GDP of The Gambia besides agriculture. By the year 2020, the tourism sector in The Gambia will contribute $18 \%$ to GDP as compared to the $13 \%$ values recorded in 2004 [4]. With the impacts of climate change, the sustained benefits derived from the coastal zone may be compromised.

The coastal zone is under continuous stress from climate change and anthropogenic activities. For instance, the establishment of human settlements and other economic developments along the coast; increasing storm intensity, temperature surge; varying precipitation patterns and; surge in sea levels [5,6]. On average, by the end of the 21st century, sea levels are expected to rise by $48 \mathrm{~cm}$ over the coastline of Africa $[1,6]$. The rise in sea levels is likely to result in: accelerated coastline destruction; flooding of low-lying regions; a rise in the recurrence and strength of storms; salinization of soil and water tables; degradation and alteration of biological systems and; involuntary migration of people [6,7]. It is predicted that about $92 \mathrm{~km}^{2}$ of land in the coastal zone of The Gambia will be submerged and inundated due to only $1 \mathrm{~m}$ sea level rise [8]. Under this scenario, The Gambia will lose its capital city, Banjul. Sea Surface Temperature (SST) and pH changes are relied upon to expand acidity levels by $0.06-0.32$ and SSTs by $0.6-2{ }^{\circ} \mathrm{C}$ by 2100 over the coastlines of Africa $[1,6]$. With high confidence, IPCC AR5 (2014) [6] reports a positive trend in SSTs over the majority of coastlines. By the year 2080, ocean level ascent could bring about losses as much as $22 \%$ of the world's coastal zone wetlands [9]. The costs of adaptation to the impacts of sea-level rise in coastal states could amount to $5-10 \%$ of GDP [10]. However, if no adaptation is undertaken, the losses due to climate change could be up to $14 \%$ of the GDP [10].

An effective approach with long-term prospects in addressing climate change impacts is it's mainstreaming into development agenda of sectoral policies [1,6,11,12]. A comprehensive risk and vulnerability assessment is a pre-requisite to ensure that right adaptation response is taken for effective integration into development plans [13]. In this study, the term risk refers to "the potential, when the outcome is uncertain, for adverse consequences of climate change on the lives, livelihoods, health, ecosystems and species, economic, social and cultural assets" [6]. The prior requirement for the mainstreaming process requires a thorough and purposeful engagement of stakeholders across varied sectors [1]. There is the need to undertake vulnerability and risk assessment in respective countries, which can be downscaled to sectoral levels to ensure recommendations are better represented and applicable. The viable and effective execution of adaptive response requires that a thorough risk assessment eludes maladaptation [13,14].

Methods and tools for evaluating risks and vulnerability to climate change impacts on coastal systems are in the formative stages of development. This study defines Vulnerability as "the degree, to which a system is susceptible to and unable to cope with, adverse effects of climate change, including climate variability and extremes" [6]. Vulnerability assessment also depends on the intended use of the assessment results, which may range from an intention to inform international and national policy or to spur community-level action [15]. Macro-level interventions typically include measures at the country level, with international and regional policy applications [15]. This level typically uses the top-down approach to assess vulnerability. Meso level interventions typically include measures at the subnational level [15]. This level uses the top-down, bottom-up or a combination of these approaches in vulnerability assessment. The micro-level measures target individuals and households where vulnerability is more frequently assessed using participative and qualitative measures for programs targeting. Though each level possesses unique requirements for analysis, they intersect in important ways; this study focuses on mixed methods between the meso and micro levels. 
At the macro level, the IPCC first developed the guidelines for assessing impacts of climate change called the 'common methodology' using the top-down approach [16]. Ever since the IPCC 'common methodology' was developed in 1991, there have been numerous attempts to use or adapt this methodology, but the focus has remained on sea-level rise as the most important issue of coastal zone vulnerability assessment [17]. The seven stages of IPCC 'common methodology' are:

Stage 1. Delineate case study area and specify accelerated sea-level rise and climatic change conditions. Stage 2. Produce an inventory of study area characteristics.

Stage 3. Identify relevant development factors.

Stage 4. Assess physical changes and natural system responses.

Stage 5. Formulate response strategies, identifying potential costs and benefits.

Stage 6. Assess the vulnerability profile and interpret the results.

Stage 7. Identify future needs and develop a plan of action [18].

This approach is most useful as an initial, baseline analysis for country-level studies where little is known about coastal vulnerability $[19,20]$. The focus of the 'common methodology' was on obtaining monetary valuations of vulnerable areas so a cost-benefit test could assess the best response option [17]. The adaptation component of the 'common methodology' focused around three generic options: retreat, accommodate or protect. This study defines adaptation as "the adjustment in natural or human systems in response to actual or expected climatic stimuli or their effects, which moderates harm or exploits beneficial opportunities" [21]. The 'common methodology' was deficient in assessing a wide range of technical, institutional, economic and cultural elements present in different localities [19,20]. The concept of vulnerability did not consider the resilience of coastal systems to various stresses like increase in temperature, flood intensity, on coastal systems. The 'common methodology' received criticism at the World Coast Conference in 1993 and some noted that if coastal vulnerability assessment supported Integrated Coastal Zone Management (ICZM) it would need revision and expansion [22].

Later, three agencies, the United States Country Studies Program (USCSP) [23], The Netherlands climate change studies assistance program and UNEP country case studies on climate change impacts and adaptation assessment [24] conducted studies in different parts of the world. The UNEP methodology, for instance, establishes a generic framework for vulnerability assessment and response to the threats posed by sea level rise and climate change. The USCSP methodology also extended from the assessment of the impacts of climate change on coastal recourses to other sectors like agriculture, livestock, water resources, human health, terrestrial vegetation, wildlife and fisheries [25]. Since these methods are based on the IPCC 'common methodology' with a single-stressor approach [26], the conceptual ideas behind these methods do not tackle these weaknesses either. The Southern Africa Vulnerability Initiative (SAVI) framework was developed in 2004 to emphasize the interconnections of multiple stressors [27]. It draws on the vulnerability literature originating in the disciplines of anthropology/sociology, economics, and disaster management. Because it focuses on root causes than suggested adaptive responses, assessments utilizing the SAVI framework are more complicated, resource-intensive, and demands complex and long-term research $[27,28]$.

The focus shifted to a bottom-up approach at the micro level where the main focus has been to understand the community members' actions, practices and strategies for community-based vulnerability, adaptation and coping strategies to climate change impacts [25]. Younus [25], for example, used the bottom-up approach in the prioritization of Vulnerability and Adaptation issues at the community level using weighted indices in coastal regions of Bangladesh. His study modified the Participatory Vulnerability Analysis method in the vulnerability and adaptation assessment. Another method used at the micro level is the Household Economy Approach (HEA). This is a livelihoods-based analytical framework developed based on multi-level analysis [29]. It was initially developed to predict food emergencies at the national level, but has since been adapted to assess an array of shocks at the local level $[30,31]$. A limitation associated with this method is that it is resource intensive and time-consuming $[29,30]$. 
At the meso level, most of the vulnerability assessments are suitable for economic strengthening interventions like poverty reduction, food security and sustainable livelihoods. They have features that are not generalizable for adoption in climate change vulnerability and impact assessments [15,32]. An example is the Local Vulnerability Index (LVI) [33], Household Vulnerability Index (HVI) [15,34,35] and the Participatory Vulnerability Analysis (PVA) [25,32]. Another example is the Household Livelihood Security Analysis (HLSA). Though the HLSA is useful in creating a comprehensive baseline and incorporates mixed methods, including participatory methods, the qualitative approach used is not generalisable outside the economics, sociology and anthropology frameworks [31,36-39]. Another method is the Risk and Vulnerability Assessment Methodology Development Project (RiVAMP). The RiVAMP is intended for vulnerability assessment in Small Island Developing States with a focus on coastal areas affected by tropical cyclones and their secondary effects [40]. This makes the RiVAMP not suitable for assessments in West Africa. There is the need for a method that incorporates a bottom-up approach which is more consistent with coastal zone management at the sub-national level $[17,20]$. This led to the development of the vulnerability and risk management framework by researchers in the Australian Greenhouse Office (AGO) in 2006 [41]. This method has been used in the development of climate change risk and vulnerability assessments in Australia and Canada [42,43]. The method employs a multi-stressor approach with fewer resources and, training time requirements in assessments [42,43]. It also identifies a more comprehensive variety of adaptations characteristically explored by researchers to deliver a simple, hands-on and representative assessment of risk and vulnerability $[13,42-45]$. We argue that a framework that considers the full process of vulnerability and adaptation will better integrate adaptation to climate change at the meso and micro levels for effective coastal zone management. This study seeks to fill this research gap by adapting the AGO methodology using the bottom-up approach at the meso level with qualitative measurements. Despite the strengths associated with this methodology, germane literature must be consulted to establish a common understanding or direction where views made from expert judgement are opposing [39].

The objective of this study is to evaluate and prioritize risks, vulnerability and adaptation issues of current and anticipated impacts of climate change on the coastal zone of The Gambia. The study will also give a methodological contribution for assessing risks, vulnerability and adaptation from the sub-national to local levels. The relevance of this study will be to create a link between the sub-national and local level in order to facilitate the integration and mainstreaming of climate change into sectoral and local policies for more climate-resilient communities. This will aid in the promotion of strategic investment of constrained developmental resources to actualize successfully dynamic coping strategies, elude 'maladaptation' and less compelling responsive measures.

\section{Materials and Methods}

Some categories of uncertainty are possible to quantify in probabilities while others are not. In the guidelines for the Fifth Assessment Report of the IPCC [6], two metrics for the communication of the degree of certainty are proposed, with one metric comprising quantified measures of uncertainty in a finding that can be expressed probabilistically. This is expressed based on statistical analysis of observations, model results or expert judgment. The other metric for the degree of certainty is expressed qualitatively and comprises confidence in the validity of a finding, based on the type, amount, quality, and consistency of evidence and the degree of agreement [6,46]. The latter metric is used in this study.

A workshop was organized for the development and validation of the impact risk and vulnerability matrix for the study area. Later, stakeholder consultations were made for further information to support the results. There are various methods to involve stakeholders, like cognitive mapping, expert judgement, brainstorming or checklists, interviews and surveys [47]. When quantitative data are not available, expert opinions of key stakeholders can offer alternative sources of information on coastal systems [6,25,46-49]. A purposive expert sampling technique was used in selecting respondents for the study. To minimize the error associated with this sampling 
technique, a quota of 20 experts were selected from each institution for the workshop. A total of 100 experts were engaged in the workshop. The steps of this study were officially communicated to the heads of the institutions. This information was later relayed to other staff members for 2 weeks, to ensure familiarization with the steps to be used for the workshop. The heads of the institutions selected the experts based on their level of expertise in climate change and their willingness to participate in the workshop. The institutions consulted are; the Department of Water Resources, Coastal and Marine Environment Unit of the National Environment Agency, Department of Parks and Wildlife Management, Department of Agriculture, Ministry of Environment, Climate Change and Natural Resources.

Thirteen (13) principal steps were used in completing the risk and vulnerability matrix during the workshop and stakeholder consultative meetings. This includes:

- Step 1: Definition of the Area of Interest and Timescale Boundaries

- Step 2: Identification of Important Climate Change Variables

- Step 3: Assigning Likely Changes in Climate Change Patterns

- Step 4: Identification of Elements of the Sector

- Step 5: Completion of the Framework of the Impact Risk Matrix

- Step 6: Description of the Climate Change Impacts

- Step 7: Determination of the Likely Category for the Impact

- Step 8: Determination of the Consequence Category for the Impact

- Step 9: Assigning Impact Risk in the Impact Risk Matrix

- Step 10: Description of Adaptation Response

- Step 11: Determination of Adaptive Capacity

- Step 12: Assigning Level of Vulnerability

- Step 13: Preparing a Risk/Vulnerability Statement.

The themes for each step is translated into the research questions for the study. For instance, in step 2-Identification of Important Climate Change Variables. The experts were asked to list 5 important climate change variables that impact the coastal zone of The Gambia. The stakeholders then went through the IPCC document, identified and listed out the 5 most important climate change variables that will impact the study area. The 5 commonest variables selected by the respondents were then ranked collectively from 1 (the most important to the study area) to 5 (the least important). These steps are expanded below:

Step 1: Definition of the Area of Interest and Timescale Boundaries

The geographical boundary was defined as the entire open coast of The Gambia (Figure 1) within the scale limits of 2100 [6]. This timeframe adopted formed the baseline climate and socio-economic scenarios for this study.

Step 2: Identification of Important Climate Change Variables

The workshop participants identified five vital variables of climate change with a momentous impact on the coastal zone of The Gambia. Although not thorough, the list provides a useful vulnerability and risk assessment of the coastal zone of The Gambia. These key climate change variables selected and the level of confidence in projection were identified from a review of the IPCC (2014) [6] report (Table 1). Table 1 below provides the identified imperative climate change variables relevant to the coastal zone sector of The Gambia. The first column ranked the climate change variables from one to five, where one is the most significant and five is the least significant for the sector. The third column shows the level of confidence scientists placed in the projection for each climate variable using color codes described in Table 2 below. 


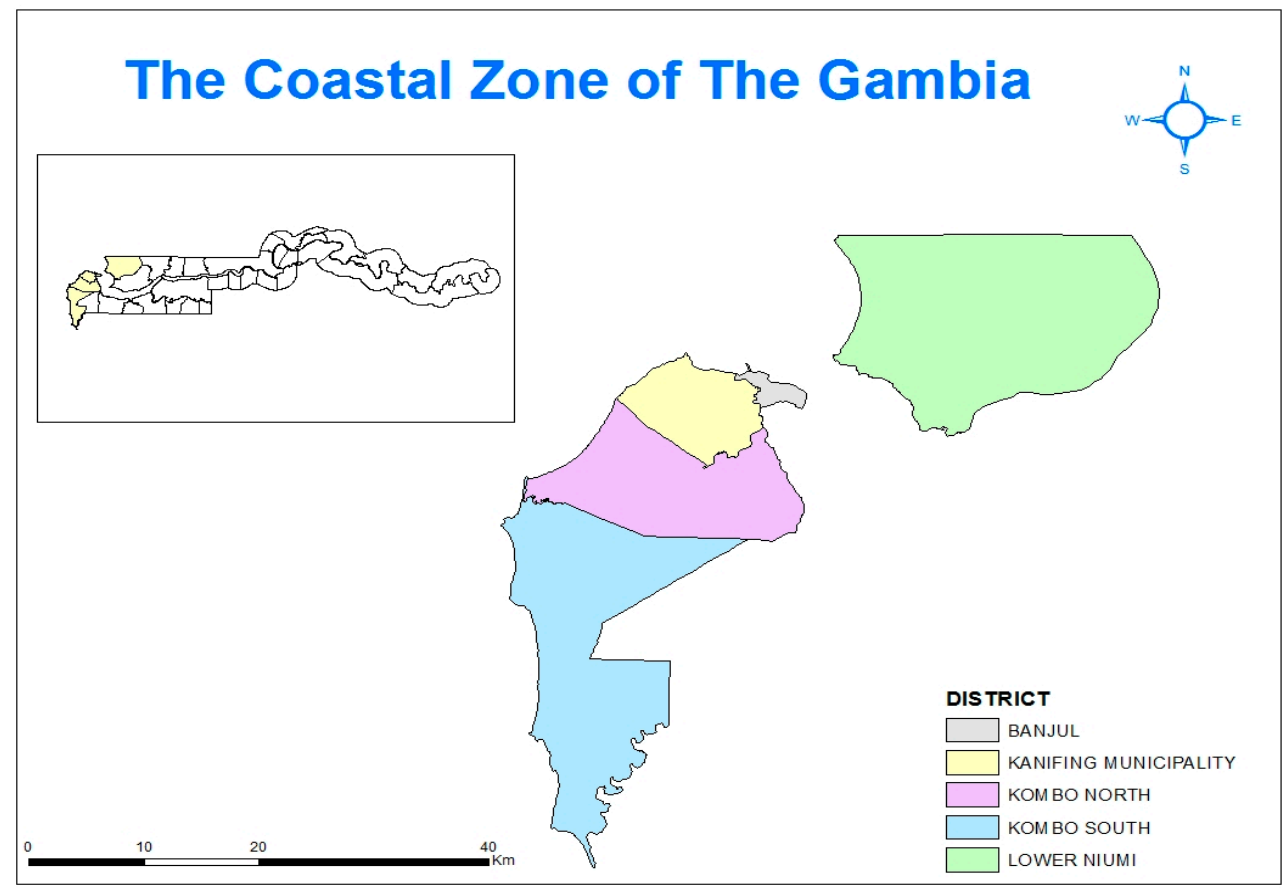

Figure 1. Map of the Study Area, the Coastal Zone of The Gambia.

Table 1. List of Climate Change Variables and the Level of Confidence in Projections.

\begin{tabular}{ccc}
\hline Priority Level & Climate Change Variables & Level of Confidence Using Color Code \\
\hline 1 & Increased Temperature & \\
2 & Sea Level Rise \\
3 & Elevated Carbon Dioxide $\left(\mathrm{CO}_{2}\right)$ levels & \\
4 & Increased Flood Severity & \\
5 & Reduced Rainfall frequency and Intensity & \\
\hline
\end{tabular}

The color code shows the level of priority assigned to the CC variables; the deep red color shows a higher priority level than light red color while the orange color shows the least priority level. Source: IPCC, 2014.

Table 2. Confidence and Likelihood of the Coastal Zone experiencing the CC Variables in Table 1.

\begin{tabular}{|c|c|c|c|}
\hline Level of Confidence & Likelihood of the Outcome & Equivalent Priority Level & Color Code \\
\hline Virtually Certain & 99-100\% probability & 1 & \\
\hline Extremely Likely & 95-99\% probability & 2 & \\
\hline Very Likely & $90-95 \%$ probability & 3 & \\
\hline Likely & $66-90 \%$ probability & 4 & \\
\hline
\end{tabular}

The color code shows the level of confidence assigned to the occurrence of the CC variables identified in Table 1; the deep red color shows a higher confidence of occurrence than light red in a decreasing order. The yellow color shows the least level of occurrence of each CC variable. Source: IPCC, 2014.

\section{Step 3: Assigning Of Likely Changes in Climate Change Patterns}

By assigning likely changes in each climate change pattern identified in step 2, the IPCC [6] report was reviewed to expose the level of confidence in each climate change projection. Four levels of confidence were assigned to the 2100 projections to the climate change variables (Table 2), namely: virtually certain; extremely likely; very likely and; likely. The reviewed literature exposing the projections in the climate change variables are discussed in the subsections below. 


\subsection{Increased Temperature}

IPCC [6] reveals air temperatures surged by over $0.5^{\circ} \mathrm{C}$ throughout last $50-100$ years over most parts of Africa. It is virtually certain that globally the troposphere has warmed since the mid-20th century. Temperatures in Africa are projected to rise faster than the global average increase during the 21st Century. In West Africa, a temperature rise of $3-6{ }^{\circ} \mathrm{C}$ is predictable by the end of the 21st century as of the late 20th Century baseline [6]. These forthcoming projections in temperature over the West Africa Sub-region will occur one to two decades earlier than the projected global average. This is due to the relatively small natural climate variability in the sub-region engendering a narrow climate limits that can be easily outshined by comparatively slight changes in climatic variables [6]. At the local level, The Gambia has recorded temperature increases of $0.5^{\circ} \mathrm{C}$ per decade from the year 1940 and it is predicted that temperatures will increase from the current levels of $28^{\circ} \mathrm{C}$ to $31.5^{\circ} \mathrm{C}$ by 2100 [6].

\subsection{Sea Level Rise (SLR)}

The IPCC [6] envisages with virtual certainty that SLR will advance further than 21st-century levels owing to continuous emissions of $\mathrm{CO}_{2}$ from both natural and anthropogenic sources. Under Low emissions scenario, sea levels are anticipated to increase to $0.26-0.55 \mathrm{~m}$ by 2100 while increases in the range $0.52-0.98 \mathrm{~m}$ are recorded in High emissions scenario [6]. The IPCC [6] forecasts with virtual certainty that near-surface permafrost size at high northern latitudes will diminish as the global mean surface temperature rises, with the size of permafrost near the surface (upper $3.5 \mathrm{~m}$ ) projected to decrease by $37-81 \%$. This will contribute to surge in sea levels from global to local levels. At the regional level, before the end of the 21st century; ocean level ascent is probably to be $10 \%$ Higher along Africa's coastlines than the worldwide mean [50].

\subsection{Elevated Carbon Dioxide Levels}

The IPCC [6] predicts with very high certainty that elevated $\mathrm{CO}_{2}$ levels with other GHG emissions in the atmosphere have resulted in an extremely likely cause of the observed warming since the mid-20th century. It is extremely likely that the increase in anthropogenic sources of $\mathrm{CO}_{2}$ and other anthropogenic GHG concentrations triggered over $50 \%$ of the observed surge in global average surface temperature from 1951 to 2010. These anthropogenic sources of $\mathrm{CO}_{2}$ have increased since the pre-industrial era, driven largely by economic and population growth through the burning of fossil fuels, and cement manufacturing processes, among others.

\subsection{Increased Flood Severity}

It is very likely that since 1951 there have been statistically significant increases in the number of heavy precipitation events in more regions than there have been statistically significant decreases [6]. This phenomenon has caused varied impacts like floods from regional to local levels [6]. Coastal systems and Low-lying areas will increasingly experience submergence, flooding, and erosion throughout the 21st century and beyond, due to SLR [6]. The contemporary detection of increasing trends in extreme precipitation besides discharges in some catchments denotes greater risks of flooding on a regional scale [6].

\subsection{Increased Rainfall Frequency and Intensity}

The frequency and intensity of heavy precipitation events have likely increased over most parts of Africa while continents like North America and Europe have experienced very likely increases [6]. It is very likely that global near-surface and tropospheric air specific humidity has increased since the 1970s. This has contributed to an increase in the frequency and intensity of rainfall, although the rainfall amounts have shown a downward trend over most parts of Sub-Sahara Africa. This is largely observed at the local level. For instance, forecasts over The Gambia point to at least $20 \%$ decrease in rainfall by mid-century with an increase in its intensity and frequency [51]. 
Step 4: Identification of Elements of the Sector

The sector elements identified are issues that affect production, natural resources, social or lifestyle aspects, particularly agricultural production, fisheries, tourism and human health and well-being in the study area (Table 3). Amongst the elements that affect production dynamics in the sector are: Land Use/Cover Changes; Infrastructure Development; Population Dynamics and; Fisheries Productivity [51]. The other sector elements that formed natural resource drivers of the coastal zone comprise: Mangroves and Wetland; Fisheries; Agricultural Land; Mining Operations; Habitat, and Biodiversity loss [51]. In this study, coastal wetlands comprise salt marshes, mangroves and intertidal areas excluding other biogenic features like coral reefs. Lastly, the sector elements that form the social or lifestyle drivers of the coastal zone include Employment; Health; Poverty; Cultural and Religious Issues and; Population Dynamics [51]. The workshop participants identified and ranked five vital elements with a momentous impact on the coastal zone of The Gambia. Overall, five elements were selected for the vulnerability assessment. The top two ranking sector elements that form the production drivers are; natural resource drivers and social or livelihood drivers. These elements are ranked from one (the highest rank) to five (lowest rank).

Table 3. Elements of the sector that are affected by Climate Change.

\begin{tabular}{ccc}
\hline Drivers of the Sector & Elements & Priority \\
\hline \multirow{3}{*}{ Production Drivers } & Land Use/Cover Change & 1 \\
& Infrastructure Development & 2 \\
& Population Dynamics & 3 \\
& Fisheries Productivity & 4 \\
\hline \multirow{5}{*}{ Natural Resources Drivers } & Mangroves and Wetland & 1 \\
& Fisheries & 2 \\
& Mining, e.g., Sand and ilmenite & 3 \\
& Habitat and Biodiversity & 5 \\
\hline \multirow{3}{*}{ Social or Lifestyle Drivers } & Employment & 1 \\
& Health & 2 \\
& Pultural and Religious Issues & 3 \\
& Population Dynamics & 5 \\
\hline
\end{tabular}

Source: Author's Computation, 2017.

Step 5: Completion of the Framework of the Impact Risk Matrix

The experts in the workshop completed each cell of the impact risk matrix independent of each other. This was done by deliberations and the establishment of an accord on the anticipated impact of each climate change variable on each key sector element identified in step 4 . The impact risk matrix framework comprises the climate change variables on the vertical axis while the key sector elements are on the horizontal axis.

Step 6: Description of the Climate Change Impacts

The participants of the workshop came to a verbal agreement and values were recorded on the anticipated impacts, whether positive or negative of each climate change variable for each principal element in the coastal zone. Varied literature sources were consulted to complement and substantiate the claims made from the expert judgement. This helps in reducing individual biases. Most impacts of the climate change element on the key sector elements were negative. These descriptions were imputed into the risk matrix, independent of each other and without external influences.

Step 7: Determination of the Likely Category for the Impact 
The likelihood of each climate change event happening was determined from one of the five categories either as almost certain, likely, possible, unlikely, or rare (Table 4). The likelihood of each event occurring was determined for each key sector element independent of each other in the impact risk matrix development. The frequency of occurrence of the climate change event is also considered as some will occur once in the year, while others may occur more than once in a year [41].

Table 4. Likelihood Categories Describing the Occurrence of Each climate change Impact.

\begin{tabular}{ccl}
\hline Rating & \multicolumn{1}{c}{ Recurrent Events } & \multicolumn{1}{c}{ Single Event } \\
\hline Almost Certain & Could occur several times per year. & More likely than not. Probability greater than 50\%. \\
\hline Likely & May arise about once per year. & As likely as not. 50/50 chance of happening. \\
\hline Possible & May arise once in 10 years. & $\begin{array}{l}\text { Less likely than not but still appreciable. } \\
\text { Probability less than 50\% but still quite High. }\end{array}$ \\
\hline Unlikely & May arise once in 10 years to 25 years. & $\begin{array}{l}\text { Unlikely but not negligible. Probability Low } \\
\text { but noticeably greater than zero. }\end{array}$ \\
\hline Rare & Unlikely during the next 25 years. & Negligible. Probability very small, close to zero. \\
\hline
\end{tabular}

Step 8: Determination of the Consequence Category for the Impact

The consequences of the impact of the climate change risk are considered for each sector element independent of each other and range from 'catastrophic' to 'minor' impacts [41]. The consequence category for the impact of the climate change variables on each key sector element was determined from one of the five categories as either catastrophic, severe, major, moderate or minor.

Step 9: Assigning Impact Risk in the Impact Risk Matrix

After the likelihood and the consequence category of the impacts were determined, Table 5 was used to combine the likelihood (step 7) and the consequences (step 8) categories in developing the level of impact risk. These values were documented for each significant sector element in completing the impact risk matrix. The overall impact of climate change for each key sector element of the coastal zone was derived by adding each cell in the specific column and communally arriving at unanimity on the overall impact (as either positive or negative). An overall impact matrix is developed and shown with shading of each cell with color codes. The darker the brown color, the greater the negative impact of the climate change variable on the key sector elements of the coastal zone of The Gambia.

Table 5. Level of Impact (Impact Risk) for Describing Negative Consequences.

\begin{tabular}{cccccc}
\hline \multirow{2}{*}{ Likelihood } & \multicolumn{5}{c}{ Consequence } \\
\cline { 2 - 6 } & Minor & Moderate & Major & Severe & Catastrophic \\
\hline Rare & Low & Low & Low & Low & Low \\
Unlikely & Low & Low & Medium & Medium & Medium \\
Possible & Low & Medium & Medium & High & High \\
Likely & Low & Medium & High & High & Extreme \\
Almost Certain & Low & Medium & High & Extreme & Extreme \\
\hline
\end{tabular}

The darker the brown color, the greater the negative impact of the climate change variable on the key sector elements of the coastal zone of The Gambia. Source: AGO, 2006.

Step 10: Description of Adaptation Response

After developing the impact risk matrix (step 9), the climate change professionals used their expert judgment to identify key adaptation responses likely to reduce the risks associated with each climate change impact on each sector element. This was then validated with the review of pertinent literature. The climate change variables and their corresponding key sector elements of the impact risk matrix are then transferred to develop the vulnerability matrix. 


\section{Step 11: Determination of Adaptive Capacity}

The level of adaptive capacity for each cell is then determined to complete the vulnerability matrix. Adaptive capacity in this study is defined as "the ability or potential of a system to adjust successfully to climate change, to moderate potential damages, to take advantage of opportunities, and/or to cope with the consequences" [6]. The coastal zone of The Gambia has a low adaptive capacity in addressing issues of climate change [51,52], the reason for the low adaptive capacity option selected for all cells. A modified form of the AGO [41] description of adaptive capacity is used: Low-this level of adaptive capacity implies it is very demanding and expensive for the coastal zone sector to actualize adaptation actions that are effective. Medium-this level of adaptive capacity identifies trouble and cost implications in actualizing change; however, it is conceivably possible within the study area. High-this level of adaptive capacity implies there is ease in adopting options placing adjustments as doable and useful.

\section{Step 12: Assigning Level of Vulnerability}

In assigning the level of vulnerability of each climate change variable on the key sector element, Table 6 is used to cross-reference the risk determined from the impact risk matrix with the adaptive capacity determined in step 11 . These values were recorded and used in developing the Vulnerability Matrix. The Vulnerability Matrix describing the Adaptation responses for the key elements of the coastal zone of The Gambia is completed with shading of each cell with color codes. The darker the pink color, the greater the vulnerability of the key sector elements to the climate change variables in the study area.

Table 6. Level of Vulnerability Derived From Combining Impact Risk and Adaptive Capacity.

\begin{tabular}{cccc}
\hline Impact & Low & Medium & High \\
\hline Extreme & High & High & Moderate \\
High & High & Moderate & Moderate \\
Medium & Moderate & Moderate & Low \\
Low & Low & Low & Low \\
\hline
\end{tabular}

The darker the pink color, the greater the vulnerability of the key sector elements to the climate change variables in the study area. Source: AGO, 2006.

\section{Step 13: Preparing a Risk or Vulnerability Statement}

The Risk or Vulnerability statement was prepared to expose the nature and level of risk or vulnerability of the coastal zone to anticipated climate change impacts, the necessity for scheduling of the response and the nature of useful adaptation responses. This helps in revealing how the identified risks can be potentially addressed in the short to long-term.

\section{Results and Discussion}

\subsection{Impact Risk Assessment}

The writings in the impact risk matrix show the direction and the impact of the climate change variables on the key sector elements in the study area (Table 7). The shaded areas indicate the impact of the climate change variables on the key sector elements. The deeper the shade of brown, the greater the impact of climate change on the sector elements in each cell of the impact risk matrix (Table 7). All the cells in the impact matrix recorded a negative impact on the key sectors of the coastal zone of The Gambia (Table 7). The impact of the climate change variables recorded range from 'High' to 'Low'. $11(44 \%)$ cells in the matrix recorded a 'High' impact, 6 (24\%) cells recorded a 'Medium' impact while 8 $(32 \%)$ cells recorded a 'Low' impact on the key sector elements in the coastal zone. The anticipated 'High' impact of climate change on the coastal zone indicates the High level of exposure of the sector element as it has a relatively Low adaptive capacity to address these impacts in The Gambia [7,51-53]. 
The climatic variables of 'increased flood severity' and 'increased temperature' recorded the highest impact on the coastal zone. The increase in temperature will likely have deleterious impacts across the sector elements like: the increase in heat stress on crops, livestock and biodiversity; reduction in water quality due to increased growth of nuisance algae. This will lead to lower oxygen levels in water bodies, among others. Although increased temperature could have detrimental effects on the study area, other areas like the tourism sector can benefit from this climate change impact until a particular threshold of temperature is achieved [54]. Increased temperature may provide prospects for outdoor tourism activities like historical and cultural site visits, increased exposure of tourists to the 'sun' with shopping activities [55]. Increased flood severity will likely have deleterious impacts on the sector elements like land use/cover changes; damage to facilities of economic, social or cultural importance owing to floods; mangrove and wetland survival; major drop in employment opportunities due to the destruction of infrastructure and; changes to the health of individuals. The key elements in the coastal zone that recorded an overall 'High' impact consist of: land use/cover changes; infrastructural development; wetlands and mangroves and; health concerns. The Employment key sector nonetheless recorded a 'Low' climate change impact on the coastal zone. With the overall High impact of the climate change variables on land use/cover changes, it is likely there will be observed impacts like severe heat stress on crops, livestock and biodiversity within the coastal zone. Yaffa [7] and NAPA [52] study further supports this claim.

The overall 'High' impact of the climate change variables on 'infrastructural development' will likely lead to impacts like major damage to facilities of economic, social and cultural importance, owing to flood events. These impacts of climate change could create a new group of refugees, who may migrate into new settlements to seek new livelihoods, which will create additional demands on infrastructure [10,56]. This may account for the observed 'High' impact of climate change on infrastructure development in the study area.

The overall 'High' impact of the climate change variables on mangroves and wetlands will likely lead to impacts like changes in their ecosystem, increase in algal blooms affecting their very survival beside affecting water quality and reduction in oxygen levels. Reduction in water quality could be attributed to changes in freshwater supply and runoff. Sustained survival of wetlands and mangrove ecosystems requires that the rate of evapotranspiration runs parallel to the rate of water supply with rainfall or from streamflow [6,57]. Increase in temperature and decrease in rainfall amounts is likely to alter this balance beside anthropogenic activities like deforestation and damming of waterways [51,52]. These factors increase the exposure of wetland and mangrove ecosystem and may account for the observed 'High' impact of climate change on this key sector element. The overall 'High' impact of the climate change variables on health is likely to cause an increase in cases of malaria, injuries and other threats to lives owing to floods and heat stress, among others.

The employment sector recorded an overall 'Low' impact of anticipated climate change events. This is likely to cause a major decrease in the productivity of employees, due to fatigue from increased temperature, dip in employment opportunities owing to the destruction of infrastructure from flood risks, among others. The overall impact risk for each sector is assessed through stakeholder consultations while developing the appropriate adaptation responses in addressing these risks in the study area.

\subsection{Vulnerability Assessment}

The writings in the vulnerability and adaptation matrix (Table 8) show the responses that agents in the areas of climate change such as Agriculture, Water Resources, Parks and Wildlife Management, Tourism can take in addressing some of the climate change impacts identified from the impact risk matrix. This list is not considered to be thoroughly exhaustive. The shades of pink in the table give a measure of vulnerability to climate change incorporating climatic impacts and adaptive capacity. The deeper the shade of pink indicates the vulnerability of climate change on the sector elements in each cell of the adaptation and vulnerability matrix (Table 8). The result of the adaptation and 
vulnerability matrix reveals that each sector element within the coastal zone of The Gambia experienced varied levels of vulnerability to climate change impacts. $10(40 \%)$ cells in the matrix recorded 'High' vulnerability, 7 (28\%) recorded 'Moderate' vulnerability and 32\% (8) recorded 'Low' vulnerability to the anticipated impacts of climate change in the study area. The coastal zone sector is highly vulnerable to increased flood severity and increased temperature. The key elements in the coastal zone that recorded an overall 'High' vulnerability to climate change comprise: infrastructural development and; wetlands and mangroves. The land use/cover changes key sector element recorded an overall 'Moderate' vulnerability with employment issues recording an overall 'Low' vulnerability to the anticipated impacts of climate change in the study area. The key sector elements that recorded 'High' vulnerability requires transformational changes in the adaptation option to ensure potential reduction of its elements to imminent impacts of the principal climate change variables under study.

With the overall 'High' vulnerability of infrastructural development, there is the need to undertake adaptation responses like the promotion of more energy efficient electrical, heating and cooling appliances with renewable energy sources and; improvement of insulation. This has become necessary as the energy will continually power industrialized processes, trade and agriculture and support the delivery of resources into sectors like the health, education, water and sanitation $[57,58]$. The accessibility of a reliable energy supply system that is effectual, reasonably priced and environmentally friendly is fundamental for advancement in all three facets of sustainable development and a condition for a shift to a green economy [58]. For instance, an institution like The Gambia Renewable Energy Centre (GREC) established in The Gambia is to promote the development of technologies and the encouragement of its use at the national and local levels. Some adaptation responses could be the improvement in regulations for restricting coastal development; engaging inhabitants in analyzing possibilities for relocation; maintaining the natural and beneficial functions of floodplains; and changes in the urban housing design like green roofing and more vents for improved ventilation, among others.

The key sector elements of wetlands and mangroves recorded an overall 'High' vulnerability to the climate change variables in the study area. Some measures taken at the national level like the Banjul Declaration in 1977 for the preclusion of the national flora and fauna endowment, including wetlands and its ecosystem have achieved minimum success [58]. And the National Disaster Management Act of The Gambia is silent on vulnerability factors with less exposition on effective adaptation measures to reduce anticipated impacts of climate change [58]. This, among other reasons, may have contributed to the observed high vulnerability to climate change impacts in the study area. There is the need to undertake adaptation responses to overcome the challenges faced in the mentioned areas. Some of the adaptation actions that can be used comprise the training of community members principally oyster harvesters on sustainable use of mangrove resources; provision of alternative livelihood support system for community members to allow for effective fallow of mangroves and wetland ecosystem. There is the need for mangrove restoration and rehabilitation of affected areas; the introduction of more flood tolerant mangrove species and; incorporation of wetland protection into regional and local infrastructure development planning. The continuous pressure from anthropogenic activities in wetland areas may likely increase their vulnerability to the varied impacts of climate change in the study area. The rate of deforestation is far beyond the rate of mangrove restoration in some wetlands of The Gambia [59]. For instance areas within the Tanbi and Bao Bolong wetland reserves are used for rice cultivation during the wet season and vegetable crop production during the dry season [59]. Others harvest the mangroves for household energy and construction needs due to poverty. This has ramifications on local and commercial fishing and oyster population. Effective implementation of the adaptation response requires a strong partnership among the public, private sector and community members [59].

Per the overall 'Moderate' vulnerability of the land use/cover changes, there is the need to undertake adaptation responses like improving crop and grazing land management for increased land cover and soil carbon storage; reduction in using fossil-based fertilizers and pesticides and; increase 
afforestation and reforestation programs (Table 8). Further adaptation responses identified include the improvement of regulations for restricting agriculture and livestock grazing activities to improve land cover and; engagement of inhabitants in analyzing possibilities for relocation from flood-prone areas. There is also the need for protection of key economic infrastructure like fish landing and tourism attraction sites; consolidation in using integrated coastal zone management; increased crop diversification and rotation to reduce total crop failure. An adaptive response like the encouragement of farmers to undertake crop diversification at the local level may be met with concerns like poverty, restraining the diverse options available to them $[10,58]$. Microfinancing and other social wellbeing nets and social welfare allowances may improve adjustment to present future stun and stresses and assist in beating such limitations if upheld by indigenous institutional plans for long-term sustainability [60].

The key sector element, employment noted an overall 'Low' vulnerability to the climate change variables in the study area. The Agriculture sector is a key contributor to Greenhouse Gases (GHGs), accounting for over $13.5 \%$ of global greenhouse gas emissions [61]. Increase in employment in this sector can be associated with a resultant increase in activities releasing more GHGs, thus exacerbating climate change impacts. Over $62.8 \%$ of the employed populace in The Gambia are in the non-agricultural informal sector and other forms of vulnerable occupations [62]. The non-agriculture informal sector may contribute less GHG emissions relative to regions with more employment in this sector. This may account for the observed low vulnerability of the employment sector elements to the anticipated impacts of climate change in the coastal zone. There is the need to undertake adaptation responses like raising more awareness of climate change risks, impacts, and adaptation with its mainstreaming into strategic and annual business plans. More research, investment, and development of clean energy and other renewable energy sources like solar energy with the significant creation of green jobs need to be explored, coupled with the development of flood response plans at the corporate level. Among other adaptation responses are the encouragement of employee training on climate change risks and disaster management with the subscription of employees to insurance policies in the face of anticipated climate change impacts.

\subsection{Climate Change Risk Statement}

It is helpful while educating administrators and key policymakers regarding dangers and vulnerabilities, to expose them to a risk statement. The risk statement synthesizes highlights from the impact, vulnerability and adaptation matrix in this paper. A case in point of a risk statement describing the risk of increased flooding severity to the coastal zone of The Gambia is:

The 'High' risk to the coastal zone of The Gambia to increased flood severity of land cover/use change, infrastructural development, and health could cause a severe impact on land use/cover changes, major damage to infrastructure of economic, social or cultural importance owing to floods as well as severe health threats from injuries and death, among others. This level of risk requires an immediate response from the most senior levels of leadership, agency management, policy development and government representatives, and individuals in the sector. This risk can be potentially addressed through improved regulations for restricting agriculture and livestock grazing activities to improve land cover; engaging inhabitants in analyzing possibilities for relocation from flood-prone areas; strengthening of early-warning systems; building flood-shelters; integrated emergency services and stakeholder response to flood events. 
Table 7. Impact Risk Matrix describing the impacts of the key elements of the coastal zone of The Gambia to climate change.

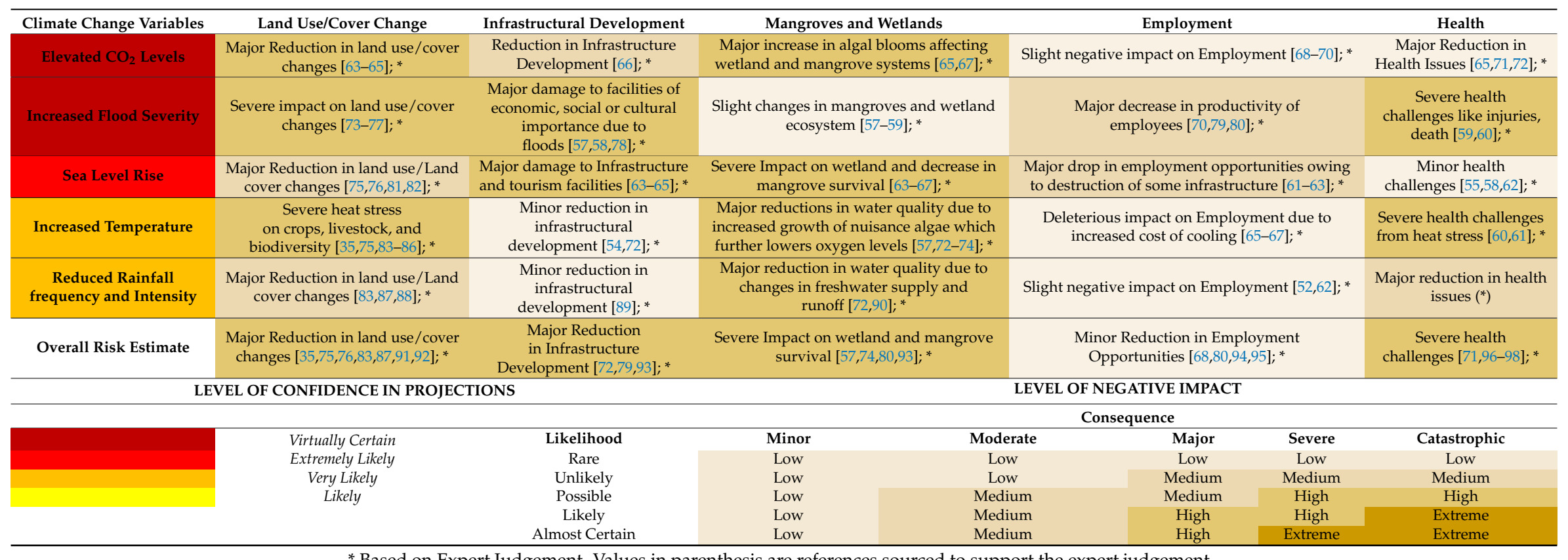

* Based on Expert Judgement. Values in parenthesis are references sourced to support the expert judgement. 
Table 8. Vulnerability Matrix describing the Adaptation responses for the key elements of the coastal zone of The Gambia.

\begin{tabular}{|c|c|c|c|c|c|}
\hline Climate Change Variables & Land Use/Cover Change & Infrastructural Development & Mangroves and Wetlands & Employment & Health \\
\hline Elevated $\mathrm{CO}_{2}$ Levels & $\begin{array}{l}\text { Improving crop and grazing land } \\
\text { management for increased land cover and } \\
\text { soil carbon storage; Reduction in using } \\
\text { fossil-based fertilizers and pesticides; } \\
\text { Increase afforestation and reforestation } \\
\text { programs [99-102]; * }\end{array}$ & $\begin{array}{l}\text { Promotion of more energy efficient } \\
\text { electric heating and cooling appliances } \\
\text { with renewable energy sources like solar } \\
\text { energy; Improvement of } \\
\text { insulation [100,102-105]; }\end{array}$ & $\begin{array}{l}\text { Training of community members principally } \\
\text { oyster harvesters on sustainable use of } \\
\text { mangrove resources; Provision of alternative } \\
\text { livelihood support system for community } \\
\text { members like sinking boreholes for } \\
\text { irrigation water supply for horticulture } \\
\text { throughout the lean season to tolerate } \\
\text { effective fallow of mangroves and wetland } \\
\text { ecosystem [106-111]; * }\end{array}$ & $\begin{array}{l}\text { Awareness raising on climate change risks, } \\
\text { impacts, and adaptation with its } \\
\text { mainstreaming into strategic and annual } \\
\text { business plans; More research, investment, } \\
\text { and development of clean energy; Use of } \\
\text { renewable energy sources like solar energy; } \\
\text { creation of green jobs [112-117]; * }\end{array}$ & $\begin{array}{l}\text { Mass Transit, pollution controls, and } \\
\text { public education; Alternative energy } \\
\text { generation from sources like Solar, } \\
\text { Biomass, Geothermal, } \\
\text { wind [114,118-120]; * }\end{array}$ \\
\hline Increased Flood Severity & $\begin{array}{l}\text { Improve regulations for restricting } \\
\text { agriculture and livestock grazing activities to } \\
\text { improve land cover; Engaging inhabitants in } \\
\text { analyzing possibilities for relocation from } \\
\text { flood-prone areas [100,101,105,121]; }\end{array}$ & $\begin{array}{l}\text { Improve regulations for restricting } \\
\text { coastal development; Engaging } \\
\text { inhabitants in analyzing possibilities for } \\
\text { relocation; Maintenance of natural and } \\
\text { beneficial functions of floodplains; } \\
\text { Construction of flood-proof } \\
\text { housing [103-105,122,123]; }\end{array}$ & $\begin{array}{l}\text { Mangrove Restoration and Rehabilitation of } \\
\text { affected areas; Introduction of more } \\
\text { floodd-tolerant mangrove } \\
\text { species }[99,108,110,115] ;{ }^{*}\end{array}$ & $\begin{array}{c}\text { Economic diversification in sectors to reduce } \\
\text { dependence on climate-sensitive resources in } \\
\text { the CZ like basket weaving, calabash design, } \\
\text { bead-making to support the local tourism } \\
\text { industry; Development of effective flood } \\
\text { response plans at the corporate } \\
\text { level [102,105,112,116,117,122,124]; * }\end{array}$ & $\begin{array}{l}\text { Strengthening of Early-warning } \\
\text { system; Building flood-shelters; } \\
\text { Integrated emergency services and } \\
\text { Stakeholder response to flood } \\
\text { events [100,118-120,125,126]; }\end{array}$ \\
\hline Sea Level Rise & $\begin{array}{l}\text { Protection of key economic infrastructures } \\
\text { like fish landing and tourism attraction sites; } \\
\text { Consolidation in using integgrated coastal } \\
\text { zone management. [100,101,108,,115,123]; }{ }^{*}\end{array}$ & $\begin{array}{c}\text { Improve regulations for restricting } \\
\text { coastal development; Engaging } \\
\text { inhabitants in analyzing possibilities for } \\
\text { relocation; Routine monitoring of the } \\
\text { coast, improving coastal defence through } \\
\text { afforestation; Increase in shoreline } \\
\text { setbacks }[99,104,105,115,127] ;{ }^{*} \\
\end{array}$ & $\begin{array}{c}\text { Use of appropriate agricultural and forestry } \\
\text { practices to increase the water retention } \\
\text { capacity; Allowance for coastal wetlands to } \\
\text { migrate inland using setbacks; Incorporation } \\
\text { of wetland protection into regional and local } \\
\text { infrastructure development } \\
\text { planning [105-107,109,111,12]; * } \\
\end{array}$ & $\begin{array}{c}\text { Employee training on climate risks and } \\
\text { disaster management; Development and } \\
\text { subscription of employees to insurance } \\
\text { policies against impacts of climate } \\
\text { change }[114,116,117,121,123,124] ;{ }^{*}\end{array}$ & $\begin{array}{l}\text { Construction of seawalls and } \\
\text { revetments }[100,102,119,123,126,128] ; * \text { * }\end{array}$ \\
\hline Increased Temperature & $\begin{array}{l}\text { Increase crop diversification and rotation to } \\
\text { reduce total crop failure; Switching to } \\
\text { drought-tolerant crop and animal species; } \\
\text { Changes to more heat tolerant livestock like } \\
\text { the shift from cattle to goat rearing; More } \\
\text { appropriate, accessible and reliable seasonal } \\
\text { and weather forecasts [100,108,115,121]; }{ }^{*}\end{array}$ & $\begin{array}{l}\text { Changes in Urban housing design like } \\
\text { green roofing and more vents for } \\
\text { improved ventilation [100,102,103,114]; * }\end{array}$ & $\begin{array}{l}\text { Use of appropriate agricultural and forestry } \\
\text { practices to increase the water retention } \\
\text { capacity; Education and Awareness Creation; } \\
\text { Identification and protection of ecologically } \\
\text { significant areas like areas of high species } \\
\text { diversity, nursery and spawning grounds; } \\
\text { Management of invasive species and } \\
\text { restoration of native } \\
\text { species [106,107,110,115,12]; }\end{array}$ & $\begin{array}{l}\text { Development and subscription of employees } \\
\text { to insurance policies against impacts of } \\
\text { climate change; Use of renewable energy } \\
\text { sources for cooling, lighting or heating } \\
\text { purposes [99,112,124,129]; }{ }^{*}\end{array}$ & $\begin{array}{l}\text { Construction of buildings with more } \\
\text { vents for improved ventilation; Green } \\
\text { Roofing to reduce Urban-Heat-Island } \\
\text { effect }[114,118,119,125,128] ;{ }^{*}\end{array}$ \\
\hline \multirow[t]{6}{*}{$\begin{array}{l}\text { Reduced Rainfall } \\
\text { frequency and Intensity }\end{array}$} & $\begin{array}{l}\text { Increase crop diversification and rotation to } \\
\text { reduce total crop failure; Educational and } \\
\text { outreach programme on conservation } \\
\text { agriculture and improved pasture and } \\
\text { graze-land management; use of water } \\
\text { conservation technique like the Zai } \\
\text { technique adopted from } \\
\text { Burkina Faso }[99,105,123,130] ;{ }^{*}\end{array}$ & $\begin{array}{l}\text { Rainwater harvesting techniques } \\
\text { incorporated in building } \\
\text { designs }[99,102,104,105,129] ; *\end{array}$ & $\begin{array}{l}\text { Incorporation of wetland protection in } \\
\text { infrastructure planning; Promotion of } \\
\text { community-based conservation } \\
\text { programmes; Education and awareness } \\
\text { creation [99,107,109,111]; * }\end{array}$ & $\begin{array}{l}\text { Rainwater harvesting techniques } \\
\text { incorporated in building } \\
\text { designs }[99,100,108,116,117] ;\end{array}$ & $\begin{array}{l}\text { Watershed Management and water } \\
\text { treatment; Public Education; } \\
\text { Changes in Urban housing design } \\
\text { [119,120,125,126,128]; }{ }^{*}\end{array}$ \\
\hline & \multicolumn{2}{|c|}{ LEVEL OF CONFIDENCE IN PROJECTIONS } & \multicolumn{3}{|c|}{ LEVEL OF VULNERABILITY TO CLIMATE CHANGE } \\
\hline & Virtually Certain & Impact & Low & Medium & High \\
\hline & $\begin{array}{l}\text { Extremely Likely } \\
\text { Very Likely }\end{array}$ & $\begin{array}{l}\text { Extreme } \\
\text { High }\end{array}$ & $\begin{array}{l}\text { High } \\
\text { High }\end{array}$ & $\begin{array}{l}\text { High } \\
\text { Moderate }\end{array}$ & $\begin{array}{l}\text { Moderate } \\
\text { Moderate }\end{array}$ \\
\hline & \multirow[t]{2}{*}{$\begin{array}{l}\text { Very Likely } \\
\text { Likely }\end{array}$} & Medium & Moderate & Moderate & Low \\
\hline & & Low & Low & Low & Low \\
\hline
\end{tabular}

* Based on Expert Judgement. Values in parenthesis are references sourced to support the expert judgement. 


\section{Conclusions}

The findings of the study reveal that by the end of the 21st century, the climatic variables likely to have the highest impact on the coastal zone of The Gambia are increased flood severity and increased temperature. The coastal zone of The Gambia showed the highest vulnerability to these climate change variables. The increase in flood severity may cause: severe impact on land use/cover changes; major damage to facilities of economic, social or cultural importance; and impacts like; severe health challenges from injuries or death. The increase in temperature may cause: severe heat stress on crops, livestock and biodiversity; major reductions in water quality due to increased growth of nuisance algae that further lowers oxygen levels, and; severe health challenges from heat stress.

The suggested adaptive response in addressing the impacts of increased flood intensity in the study area include: improving regulations for restricting agriculture and livestock grazing activities to improve land cover; engaging inhabitants in analyzing possibilities for relocation from flood-prone areas and; strengthening of an early-warning system, among others. The suggested adaptive response in addressing the increase in temperature in the study area include: increased crop diversification and rotation to reduce total crop failure; switching to drought-tolerant crop varieties and animal species; changes to more heat tolerant livestock like the shifting from cattle to sheep and goat rearing, or other ruminants.

There is the need to build and develop the capacity of various stakeholders in the coastal zone sector in order to facilitate the mainstreaming of the adaptive responses identified in this study into plans, policies and strategies at all levels to increase resilience to climate change impacts.

Acknowledgments: We are grateful to the German Government, German Federal Ministry of Education and Research (BMBF) and the West African Science Service Center on Climate Change and Adapted Land Use (WASCAL) for the scholarship of the Corresponding author (J.A.) and their financial contribution towards this research. J.A. is grateful to Mrs Theresa Aniagyei-Bonsu for all her enormous support and motivation. Special thanks to the staff of the Department of Water Resources, Coastal and Marine Environment Unit of the NEA, Department of Parks and Wildlife Management, Department of Agriculture, Ministry of Environment, Climate Change and Natural Resources for their time and useful contributions in the workshop leading to this study. We are also grateful to all other anonymous contributors and reviewers of this work.

Author Contributions: The paper is part of the correspondence author's MSc degree Thesis with the other authors serving as advisors. J.A. designed the research, methodology, collected the data, analysed the results of the study and developed the manuscript. The second and third authors are advisors that provided supervision, comments and directives at all stages. The fourth author commented on the manuscript.

Conflicts of Interest: The authors declare no conflict of interest. The sponsors or funding agency had no role in the design of the study; in the collection, analyses, or interpretation of data; in the writing of the manuscript, and in the decision to publish the results.

\section{References}

1. ECOWAS Policy brief. West Africa Coastal Climate Change National Adaptation Planning Workshop; ECOWAS Policy Brief: Accra, Republic of Gambia, 2013; pp. 4-7.

2. Becken, S.; Hay, J.E. Tourism and Climate Change: Risks and Opportunities; Multilingual Matters: Clevedon, UK, 2007; Volume 1.

3. World Tourism Organization (UNWTO). UNWTO world tourism barometer. U. N. World Tour. Organ. 2017, 5, 1-15.

4. Department of State for Tourism and Culture, Republic of The Gambia. GTDMP The Gambia Tourism Development Master Plan. Afr. Dev. Bank 2006, 1, 1-133.

5. Wrathall, C.C. Propagation and Transplanting Techniques for Native Plant Species: Living Shorelines Applications in Atlantic Canada. Master's Thesis, Saint Mary's University, Halifax, NS, Canada, 2016; pp. 1-149.

6. Intergovernmental Panel on Climate Change (IPCC). Climate Change 2014-Impacts, Adaptation and Vulnerability: Regional Aspects; Cambridge University Press: Cambridge, UK, 2014.

7. Yaffa, S. Coping measures not enough to avoid loss and damage from drought in the North Bank Region of The Gambia. Int. J. Glob. Warm. 2013, 5, 467-482. [CrossRef] 
8. Jallow, B.P.; Barrow, M.K.; Leatherman, S.P. Vulnerability of the coastal zone of The Gambia to sea level rise and development of response strategies and adaptation options. Clim. Res. 1996, 6, 165-177. [CrossRef]

9. Nicholls, R.J.; Hoozemans, F.M.; Marchand, M. Increasing flood risk and wetland losses due to global sea-level rise: Regional and global analyses. Glob. Environ. Chang. 1999, 9, S69-S87. [CrossRef]

10. Sem, G. The Impact of Climate Change on the Development Prospects of the Least Developed Countries and Small Island Developing States; WHO: Geneva, Switzerland, 2009.

11. United Nations Economic Commission for Africa (UNECA). Harnessing Agricultural Potential for Growth and Development in West Africa; United Nations Economic Commission for Africa: Addis Ababa, Ethiopia, 2012; Volume 1, pp. 1-12.

12. World Bank Indicators IData. Available online: https://data.worldbank.org/indicator (accessed on 9 December 2017).

13. Abuodha, P.A.; Woodroffe, C.D. International Assessments of the Vulnerability of the Coastal Zone to Climate Change, Including an Australian Perspective; University of Wollongong Australia: Wollongong, Australia, 2006; Volume 69, pp. 1-84.

14. Warrick, R.A. Strategies for vulnerability and adaptation assessment in the context of national communications. Asia-Pac. J. Environ. Dev. 2000, 7, 43-51.

15. Moret, W. Vulnerability Assessment Methodologies: A Review of the Literature; FHI 360: Washington, DC, USA, 2014.

16. Carter, T.R.; Parry, M.L.; Harasawa, H.; Nishioka, S. IPCC Technical Guidelines for Assessing Climate Change Impacts and Adaptations with a Summary for Policy Makers and a Technical Summary; University College London: London, UK; Center for Global Environmental Research: Tsukuba, Japan, 1994.

17. Harvey, N.; Clouston, E.; Carvalho, P. Improving coastal vulnerability assessment methodologies for integrated coastal zone management: An approach from South Australia. Geogr. Res. 1999, 37, 50-69. [CrossRef]

18. Intergovernmental Panel on Climate Change (IPCC); Coastal Zone Management Subgroup (CZMS). A common methodology for assessing vulnerability to sea level rise. In Global Climate Change and the Rising Challenge of the Sea; Report of the Coastal Zone Management Subroup, Response Strategies Working Group of the Intergovernmental Panel on Climate Change, Ministry of Transport, Public Works and Water Management, The Hague, Appendix C; IPCC: Geneva, Switzerland, 1992.

19. Kay, R.C.; Eliot, I.; Caton, B.; Morvell, G.; Waterman, P. A review of the intergovernmental panel on climate change's common methodology for assessing the vulnerability of coastal areas to sea-level rise. Coast. Manag. 1996, 24, 165-188. [CrossRef]

20. Waterman, P. Review of the applicability of the "Common Methodology for Assessment of Vulnerability of Sea-Level Rise" to the Australian Coastal Zone. In Proceedings of the IPCC Eastern Hemisphere Workshop on the Vulnerability Assessment of Sea-level Rise and Coastal Zone Management, Tsukuba, Japan, 3-6 August 1993; pp. 237-248.

21. Parry, M.; Canziani, O.; Palutikof, J.; van der Linden, P.J.; Hanson, C.E. Climate Change 2007: Impacts, Adaptation and Vulnerability; Cambridge University Press: Cambridge, UK, 2007; Volume 4.

22. Bijlsma, L.; Crawford, M.; Ehler, C.; Hoozemans, F.; Jones, V.; Klein, R.; Miermet, B.; Mimura, N.; Misdorp, R.; Nicholls, R. World Coast Conference Report. In Proceedings of the World Coast Conference, Noordwijk, The Netherlands, 1-5 November 1993.

23. Benioff, R.; Guill, S.; Lee, J. Vulnerability and Adaptation Assessments: An International Handbook; Springer Science \& Business Media: New York, NY, USA, 2012; Volume 7.

24. O'Brien, K. Developing Strategies for Climate Change: The UNEP Country Studies on Climate Change Impacts and Adaptations Assessment; Report/CICERO-Senter Klimaforskning. 2000. Available online: http:/ / urn.nb.no/URN:NBN:no-3645 (accessed on 5 February 2018).

25. Younus, M.A.F. An assessment of vulnerability and adaptation to cyclones through impact assessment guidelines: A bottom-up case study from Bangladesh coast. Nat. Hazards 2017, 89, 1437-1459. [CrossRef]

26. Klein, R.J.; Nicholls, R.J. Assessment of coastal vulnerability to climate change. Ambio 1999, 28, $182-187$.

27. O'Brien, K.; Quinlan, T.; Ziervogel, G. Vulnerability interventions in the context of multiple stressors: Lessons from the Southern Africa Vulnerability Initiative (SAVI). Environ. Sci. Policy 2009, 12, 23-32. [CrossRef] 
28. Casale, M.; Drimie, S.; Quinlan, T.; Ziervogel, G. Understanding vulnerability in southern Africa: Comparative findings using a multiple-stressor approach in South Africa and Malawi. Reg. Environ. Chang. 2010, 10, 157-168. [CrossRef]

29. Boudreau, T.; Lawrence, M.; Holzmann, P.; O’Donnell, M.; Adams, L.; Holt, J.; Hammond, L.; Duffield, A. The Practitioners' Guide to the Household Economy Approach; the Regional Hunger and Vulnerability Programme, Save the Children; The Food Economy Group: London, UK, 2008.

30. Petty, C.; Seaman, J. A new household economy method for assessing impact of shocks. Field Exch. 2004, 23, $10-12$.

31. Frankenberger, T.R.; Mock, N.; Jere, P. Vulnerability Assessment Methodology Review Synthesis; Tango International (Commissioned by SADC): Tucson, AZ, USA, 2005.

32. Chiwaka, E.; Yates, R. Participatory Vulnerability Analysis: A Step-by-Step Guide for Field Staff; Action Aid International: London, UK, 2005; pp. 1-35.

33. Naudé, W.; McGillivray, M.; Rossouw, S. Measuring the Vulnerability of Subnational Regions; Research paper/UNU-WIDER; United Nations University: New York, NY, USA, 2008.

34. Hahn, M.B.; Riederer, A.M.; Foster, S.O. The Livelihood Vulnerability Index: A pragmatic approach to assessing risks from climate variability and change-A case study in Mozambique. Glob. Environ. Chang. 2009, 19, 74-88. [CrossRef]

35. Wen-Jian, H.; Hai-Shan, C. Impacts of regional-scale land use/land cover change on diurnal temperature range. Adv. Clim. Chang. Res. 2013, 4, 166-172. [CrossRef]

36. Cannon, T.; Twigg, J.; Rowell, J. Social Vulnerability, Sustainable Livelihoods and Disasters; Department for International Development (DFID): London, UK, 2003.

37. Frankenberger, T.R.; Luther, K.; Becht, J.; McCaston, M.K. Household Livelihood Security Assessments: A Toolkit for Practitioners; TANGO International Inc.: Tucson, AZ, USA, 2002.

38. Lindenberg, M. Measuring household livelihood security at the family and community level in the developing world. World Dev. 2002, 30, 301-318. [CrossRef]

39. Rahman, S.; Akter, S. Determinants of Livelihood Security in Poor Settlements in Bangladesh; International Working Paper Series; University of Plymouth: Plymouth, UK, 2010.

40. Estrella, M.; Peduzzi, P.; Chatenoux, B.; Velegrakis, A.; Kluser, S.; Orlyk, E.; Potocnik, M.; Thakur, R. Risk and Vulnerability Assessment Methodology Development Project (RiVAMP): Linking Ecosystems to Risk and Vulnerability Reduction; The Case of Jamaica; Results of the Pilot Assessment; United Nations Environment Programme (UNEP): Washington, DC, USA, 2010; pp. 1-130.

41. Australia Greenhoues Office (AGO). Climate Change Impacts and Risk Management; Australia Greenhoues Office: Perth, Australia, 2006; pp. 1-21.

42. Brundell, J.; Cobon, D.; Stone, G.; Cliffe, N. Climate Change Risk Management Matrix: A Process for Assessing Impacts, Adaptation, Risk and Vulnerability; Workbook; Queensland Climate Change Centre of Excellence (QCCCE), Department of Environment and Resource Management: Brisbane, Australia, 2010; pp. 1-24.

43. Cobon, D.H.; Stone, G.S.; Carter, J.O.; Scanlan, J.C.; Toombs, N.R.; Zhang, X.; Willcocks, J.; McKeon, G.M. The climate change risk management matrix for the grazing industry of northern Australia. Rangel. J. 2009, 31, 31-49. [CrossRef]

44. Howden, S.M.; Soussana, J.-F.; Tubiello, F.N.; Chhetri, N.; Dunlop, M.; Meinke, H. Adapting agriculture to climate change. Proc. Natl. Acad. Sci. USA 2007, 104, 19691-19696. [CrossRef] [PubMed]

45. Stokes, B.C.J.; Ash, A.; Howden, S.M. Climate Change Impacts on Australian Rangelands. Rangelands 2008, 30, 40-46. [CrossRef]

46. Mastrandrea, M.D.; Heller, N.E.; Root, T.L.; Schneider, S.H. Bridging the gap: Linking climate-impacts research with adaptation planning and management. Clim. Chang. 2010, 100, 87-101. [CrossRef]

47. Ziervogel, G.; Zermoglio, F. Climate change scenarios and the development of adaptation strategies in Africa: Challenges and opportunities. Clim. Res. 2009, 40, 133-146. [CrossRef]

48. Malone, E.L.; Engle, N.L. Evaluating regional vulnerability to climate change: Purposes and methods. Wiley Interdiscip. Rev. Clim. Chang. 2011, 2, 462-474. [CrossRef]

49. Salter, J.; Robinson, J.; Wiek, A. Participatory methods of integrated assessment-A review. Wiley Interdiscip. Rev. Clim. Chang. 2010, 1, 697-717. [CrossRef] 
50. Schellnhuber, H.J.; Hare, B.; Serdeczny, O.; Schaeffer, M.; Adams, S.; Baarsch, F.; Schwan, S.; Coumou, D.; Robinson, A.; Vieweg, M. Turn Down the Heat: Climate Extremes, Regional Impacts, and the Case for Resilience; The World Bank: Washington, DC, USA, 2013.

51. UNFCCC. National Climate Committee Second National Communication of the Republic of The Gambia to the United Nations Framework Convention on Climate Change; United Nations Framework Convention on Climate Change (UNFCCC): Bonn, Germany, 2013; pp. 1-163.

52. Government of The Gambia. The Gambia National Adaptation Programme of Action (NAPA) on Climate Change; Government of The Gambia: Banjul, Gambia, 2007.

53. Camara, I. Mainstreaming Climate Change Resilience into Development Planning in The Gambia; International Institute for Environment: London, UK, 2013; pp. 1-12.

54. GT BOARD. Tourism Statistics Annual Report, (April); Statistics and Tourism Information Department: Phnom Penh, Cambodia, 2016; pp. 1-69.

55. African Development Bank (ADB). Africa Tourism Monitor; African Development Bank: Tunis, Tunisia, 2014; Volume 2, pp. 12-53.

56. UN-Habitat. State of the World's Cities 2008/2009: Harmonious Cities; UN-Habitat: Nairobi, Kenya, 2008; pp. 1-18.

57. Ceesay, A.; Dibi, N.H.; Njie, E.; Wolff, M.; Koné, T. Mangrove Vegetation Dynamics of the Tanbi Wetland National Park in The Gambia. Environ. Ecol. Res. 2017, 5, 145-160. [CrossRef]

58. UNDP Rio+20. Republic of The Gambia National Report; UNDP: New York, NY, USA, 2012; pp. 1-39.

59. National Environment Agency (NEA). Enhancing the Income Generation Potential and Environmental Sustainability of Fisheries Activities in Bao Bolong and Tanbi Wetlands; NEA: Singapore, 2014; pp. 1-105.

60. Chigwada, J. Case study 6: Zimbabwe climate proofing infrastructure and diversifying livelihoods in Zimbabwe. IDS Bull. 2005, 36, 103-116. [CrossRef]

61. Bosello, F.; Roson, R.; Tol, R.S. Economy-wide estimates of the implications of climate change: Human health. Ecol. Econ. 2006, 58, 579-591. [CrossRef]

62. Nshimyumuremyi, A.; Arvanitis, Y.; Gassama, K.; Lal, R.; Janneh, A. The Gambia: African Economic Outlook; Organisation for Economic Co-operation and Development (OECD): Paris, France, 2017; pp. 1-21. Available online: www.africaneconomicoutlook.org (accessed on 5 February 2018).

63. Afrane, Y.A.; Lawson, B.W.; Githeko, A.K.; Yan, G. Effects of microclimatic changes caused by land use and land cover on duration of gonotrophic cycles of Anopheles gambiae (Diptera: Culicidae) in western Kenya highlands. J. Med. Entomol. 2005, 42, 974-980. [CrossRef] [PubMed]

64. Chase, T.N.; Pielke, R.A.; Kittel, T.G.F.; Zhao, M.; Pitman, A.J.; Running, S.W.; Nemani, R.R. Relative climatic effects of landcover change and elevated carbon dioxide combined with aerosols: A comparison of model results and observations. J. Geophys. Res. Atmos. 2001, 106, 31685-31691. [CrossRef]

65. Lawrence, D.; Vandecar, K. Effects of tropical deforestation on climate and agriculture. Nat. Clim. Chang. 2015, 5, 27-36. [CrossRef]

66. Ribeiro, S.K.; Kobayashi, S.; Beuthe, M.; Gasca, J.; Greene, D.; Lee, D.S.; Muromachi, Y.; Newton, P.J.; Plotkin, S.; Sperling, D. Transportation and Its Infrastructure; Institute of Transportation Studies (UCD): Davis, CA, USA, 2007.

67. McKee, K. Fact Sheet 2006-3074. In Potential Effects of Elevated Atmospheric Carbon Dioxide on Coastal Wetlands; United States Geological Survey (USGS): Reston, VA, USA, 2006; pp. 2-4.

68. Olsen, L. The Employment Effects of Climate Change and Climate Change Responses: A Role for International Labour Standards? Global Union Research Network (GURN): Geneve, Switzerland, 2009.

69. Vergara, W.; Rios, A.R.; Galindo, L.M.; Gutman, P.; Isbell, P.; Suding, P.H.; Samaniego, J. The Climate and Development Challenge for Latin America and the Caribbean; Inter-American Development Bank: Washington, DC, USA, 2013.

70. Wei, D. Economic Impact of Sea Level Rise to the City of Los Angeles; Final Report; Price School of Public Policy and Centre for Risk and Economic Analysis of Terrorism Events; University of Southern California: Los Angeles, CA, USA, 2013; pp. 1-84.

71. Frumkin, H.; Hess, J.; Luber, G.; Malilay, J.; McGeehin, M. Climate change: The public health response. Am. J. Public Health 2008, 98, 435-445. [CrossRef] [PubMed] 
72. Zhong, S.; Qian, Y.; Zhao, C.; Leung, R.; Wang, H.; Yang, B.; Fan, J.; Yan, H.; Yang, X.-Q.; Liu, D. Urbanization-induced urban heat island and aerosol effects on climate extremes in the Yangtze River Delta region of China. Atmos. Chem. Phys. 2017, 17, 5439-5457. [CrossRef]

73. Brebante, B.M. Analyzing the Effects of Land Cover/Land Use Changes on Flashflood: A Case Study of Marikina River Basin, Philippines; ITC: Kolkata, India, 2017; Volume 1, pp. 1-62.

74. Luce, C.H. Land use and land cover effects on runoff processes: Fire. Encycl. Hydrol. Sci. 2005, 1-7. [CrossRef]

75. Mutiibwa, D.; Kilic, A.; Irmak, S. The Effect of Land Cover/Land Use Changes on the Regional Climate of the USA High Plains. Climate 2014, 2, 153-167. [CrossRef]

76. Ometto, J.P.H.; Sampaio De Oliveira, G.; Marengo, J.; Assis, T.; Tejada, G.; Aguiar, A.P. Climate Change and Land Use Change in Amazonia; Amazonia Security Agenda Project; Earth System Science Center (CCST) and Brazilian Institute for Space Research (INPE): Sao Paulo, Brazil, 2013; pp. 1-57.

77. Schultz, G.A. Changes in Flood Characteristics Due To Land Use Changes in a River Basin; Institute of Hydrology, Water Resources Management and Environmental Techniques Ruhr University: Bochum, Germany, 1995; pp. 1-13.

78. Deshmukh, A.; Ho Oh, E.; Hastak, M. Impact of flood damaged critical infrastructure on communities and industries. Built Environ. Proj. Asset Manag. 2011, 1, 156-175. [CrossRef]

79. Mangrove Ecosystems for Climate Change Adaptation \& Livelihoods (MESCAL). Impacts of Projected Climate Change on Mangrove and Coastal Ecosystems and Community Livelihoods in Solomon Islands, Vanuatu, Fiji, Tonga, and Samoa; Mangrove Ecosystems for Climate Change Adaptation: Suva, Fiji, 2013; pp. 1-42.

80. Koen, R. Assessing the Implications of Climate Change Adaptation on Employment in the EU. Neth. Organ. Appl. Sci. Res. 2014, 1-32. Available online: https://ec.europa.eu/clima/sites/clima/files/adaptation/ what/docs/climate_change_employment_eu_en.pdf (accessed on 5 February 2018).

81. Balukkarasu, A.; Prabhakaran, R.; Kumaravel, S. Assessment of Land Use/Land Cover Changes and Sea Level Rise in Parts of Southern Tamil Nadu, India. Int. J. Remote Sens. Geosci. 2009, 477, 9-15.

82. Nicholls, R.J. Case study on sea-level rise impacts. In Proceedings of the OECD Workshop on the Benefits of Cliamte Policy: Improving Information for Policy Makers, Paris, France, 12-13 December 2002; Dokument ENV /EPOC/GSP; Volume 9, pp. 69-86.

83. Babalola, O.S.; Akinsanola, A.A. Change Detection in Land Surface Temperature and Land Use Land Cover over Lagos Metropolis, Nigeria. J. Remote Sens. GIS 2016, 5, 2-19. [CrossRef]

84. Rasul, G.; Ibrahim, F. Urban Land Use Land Cover Changes and Their Effect on Land Surface Temperature: Case Study Using Dohuk City in the Kurdistan Region of Iraq. Climate 2017, 5, 13.

85. Nduati, E.W.; Mundia, C.N.; Ngigi, M.M. Effects of vegetation change and land use/land cover change on land surface temperature in the mara ecosystem. Int. J. Sci. Res. 2013, 2, 22-28.

86. Omran, E.-S.E. Detection of land-use and surface temperature change at different resolutions. J. Geogr. Inf. Syst. 2012, 4, 189. [CrossRef]

87. Mwaniki, W.M. Assessment of the Effects of Climate Change on Land Use and Land Cover Using Remote Sensing: A Case Study from Kenya. 2015, Volume 3, pp. 1-28. Available online: http:/ / collections.unu.edu/ eserv/UNU:5940/DNC_WorkingPaper_No3.pdf (accessed on 5 February 2018).

88. Pielke, R.A.; Adegoke, J.; Beltrán-Przekurat, A.; Hiemstra, C.A.; Lin, J.; Nair, U.S.; Niyogi, D.; Nobis, T.E. An overview of regional land-use and land-cover impacts on rainfall. Tellus B 2007, 59, 587-601. [CrossRef]

89. Bradbury, J.; Allen, M.; Dell, R. Climate Change and Energy Infrastructure Exposure to Storm Surge and Sea-Level Rise. Master's Thesis, Office of Energy Policy and Systems Analysis, U.S. Department of Energy, Washington, DC, USA, 2015; pp. 1-28.

90. Alongi, D.M. Mangrove forests: Resilience, protection from tsunamis, and responses to global climate change. Estuar. Coast. Shelf Sci. 2008, 76, 1-13. [CrossRef]

91. Dia Ibrahima, M. Vulnerability Assessment of Central Coast Senegal (Saloum) and The Gambia Marine Coast and Estuary to Climate Change Induced Effects; Coastal Resources Center and WWF-WAMPO, University of Rhode Island: Kingston, RI, USA, 2012; pp. 1-40.

92. Youneszadeh, S.; Amiri, N.; Pilesjo, P. The effect of land use change on land surface temperature in The Netherlands. Int. Arch. Photogramm. Remote Sens. Spat. Inf. Sci. 2015, 40, 745. [CrossRef]

93. Short, F.T.; Kosten, S.; Morgan, P.A.; Malone, S.; Moore, G.E. Impacts of climate change on submerged and emergent wetland plants. Aquat. Bot. 2016, 135, 3-17. [CrossRef] 
94. Asuncion, R.C.; Lee, M. Impacts of Sea Level Rise on Economic Growth in Developing Asia; Economics Working Papers; Asian Development Bank (ADB): Manila, Philippines, 2017; Volume 507, pp. 1-23. [CrossRef]

95. Alleng, G. Understanding the Economics of Climate Adaptation in Trinidad and Tobago; handle/11319/6512; Inter-American Development Bank: Washington, DC, USA, 2014; pp. 1-32.

96. Vellinga Climate Change 2013-The Physical Science Basis: Working Group I Contribution to the Fifth Assessment Report of the Intergovernmental Panel on Climate Change. Camb. Core 2015, 1, 1-80. [CrossRef]

97. Doocy, S.; Daniels, A.; Packer, C.; Dick, A.; Kirsch, T.D. The human impact of Climate Change: A historical review of events 1980-2009 and systematic literature review. PLoS Curr. 2013, 5, 1-32. [CrossRef]

98. Hassan, K.E. Impacts of future climate change on Egyptian population. In Proceedings of the XXVII IUSSP International Population Conference, Busan, Korea, 26-31 August 2013; pp. 1-15.

99. Besada, H.; Sewankambo, N.K. Climate change in Africa. The Centre for International Governance Innovation-Google Search; Center Internation Governance Innovation: Waterloo, ON, USA, 2009; pp. 1-172. [CrossRef]

100. Nuclear Regulatory Commission (NRC). Adapting to the Impacts of Climate Change. In Integrating Climate Change Adaptation into Development Co-operation: Policy Guidance; Organisation for Economic Co-operation and Development: Paris, France, 2010; pp. 47-54.

101. Raymond, C.L.; Peterson, D.L.; Rochefort, R.M. Climate Change Vulnerability and Adaptation in the North Cascades Region, Washington; General Technical Report-Pacific Northwest Research Station; USDA Forest Service: Washington, DC, USA, 2014; pp. 1-279.

102. USAID. Climate Change Adaptation Plan; United States Agency for International Development: Washington, DC, USA, 2012; pp. 1-123.

103. Chinowsky, P.S.; Schweikert, A.E.; Strzepek, N.L.; Strzepek, K. Infrastructure and climate change: A study of impacts and adaptations in Malawi, Mozambique, and Zambia. Clim. Chang. 2015, 130, 49-62. [CrossRef]

104. Verchick, R.R.; Hall, A. Adapting to Climate Change While Planning for Disaster: Footholds, Rope Lines, and the Iowa Floods. BYU Rev. 2011, 2011, 1-22.

105. Hallegatte, S. Strategies to adapt to an uncertain climate change. Glob. Environ. Chang. 2009, 19, $240-247$. [CrossRef]

106. Boer, H. Policy options for, and constraints on, effective adaptation for rivers and wetlands in northeast Queensland. Australas. J. Environ. Manag. 2010, 17, 154-164. [CrossRef]

107. Secretariat, C.B.D. Connecting Biodiversity and Climate Change Mitigation and Adaptation: Report of the Second Ad Hoc Technical Expert Group on Biodiversity and Climate Change, Montreal; Convention on Biological Diversity Technical Series; Department of Biological Sciences, Faculty of Science, Macquarie University: Sydney, Australia, 2009; Volume 41, pp. 1-6.

108. EPA. Climate Change Adaptation Implementation Plan; Office of Solid Waste and Emergency Response: Washington, DC, USA, 2013; pp. 1-41.

109. European Union Nature's role in Climate Change. Nat. Biodivers. 2009, 1-4.

110. Murdiyarso, D.; Kauffman, J.B. Addressing Climate Change Adaptation and Mitigation in Tropical Wetland Ecosystems of Indonesia; Center for Internatinal Forestry Research (CIFOR): Bogor, Indonesia, 2011; Volume 41.

111. Powell, N.; Osbeck, M.; Tan, S.B.; Toan, V.C. Mangrove Restoration and Rehabilitation for Climate Change Adaptation in Vietnam; World Resources Report Case Study: Washington, DC, USA, 2007.

112. UNEP. Climate Change, Its Consequences on Employment and Trade Union Action; A Training Manual for Workers and Trade Unions; UNEP: Nairobi, Kenya, 2008.

113. Ahmed, S. Green Jobs in the Era of Changing Climate; Policy Brief GSDR; University of Arizona: Tuscon, Arizona, 2015; pp. 1-4.

114. Camarsa, G.; Toland, J.; Eldridge, J.; Nottingham, S.; Hudson, T.; Jones, W.; Thevignot, C. LIFE and Climate Change Adaptation; European Commission: Brussels, Belgium, 2015; pp. 1-325. [CrossRef]

115. Maunsell, A. City of Melbourne Climate Change Adaptation Strategy; Australian Department of Industry: Canberra, Australia, 2009; pp. 1-16.

116. Pettengell, C. Climate Change Adaptation: Enabling people living in poverty to adapt. Oxfam Policy Pract. Clim. Chang. Resil. 2010, 6, 1-48.

117. Congress, Trades Union (TUC). Changing Work in a Changing Climate: Adaptation to Climate Change in the UK-New Research on Implications for Employment; Trades Union Congress: London, UK, 2009. Available online: http://www.tuc.org.uk/sites/default/files/extras/adaptation.pdf (accessed on 5 February 2018). 
118. Benjamin, G. Public Health and Climate Change: A Guide for Increasing the Capacity of Local Public Health Departments; Resource Innovation Group: Eugene, OR, USA, 2005; Volume 172, pp. 1680-1681.

119. Dimitrios, S.; Sofia, K.; Alexandros, M.; Evangelos, F.; Lambrini, K. Climate change impacts on human health. Jt. Off. Clim. Health 2014, 1, 1-9.

120. McIver, L.; Kim, R.; Woodward, A.; Hales, S.; Spickett, J.; Katscherian, D.; Hashizume, M.; Honda, Y.; Kim, H.; Iddings, S. Health impacts of climate change in Pacific island countries: A regional assessment of vulnerabilities and adaptation priorities. Environ. Health Perspect. 2016, 124, 1707. [CrossRef] [PubMed]

121. OECD. Agriculture and Climate Change. Trade Agric. Dir. Organ. Econ. Coop. Dev. 2015, 1-6. Available online: https:/ / www.eea.europa.eu/signals/signals-2015/articles/agriculture-and-climate-change (accessed on 5 February 2018).

122. Alston, M. Women and Climate Change in Bangladesh; Routledge: London, UK, 2015.

123. UNFCCC. Climate Change: Impacts, Vulnerabilities and Adaptation in Developing Countries. U. N. Framew. Conv. Clim. Chang. 2007, 104, 1-68.

124. Martinez-Fernandez, C.; Hinojosa, C.; Miranda, G. Green jobs and skills: The local labour market implications of addressing climate change. Work. Doc. OECD 2010, 1-70. [CrossRef]

125. Luber, G. CLIMATE CHANGE: Mastering the Public Health Role. Am. Public Health Assoc. 2011, 1-83.

126. Warren, F.J.; Lemmen, D.S. Canada in a Changing Climate: Sector Perspectives on Impacts and Adaptation; Natural Resources Canada: Ottawa, ON, Canada, 2014.

127. UNDP-UNEP. Making the Case for Ecosystem-Based Adaptation: Building Resilience to Climate Change; United Nations Environment Programme; United Nations Development Program: Washington, DC, USA, 2010; pp. 1-12.

128. ADB. Accounting for Health Impacts of Climate Change; Asian Development Bank: Tokyo, Japan, 2011; pp. 1-45.

129. US-EPA. Synthesis of Adaptation Options for Coastal Areas; U.S. Environmental Protection Agency: Washington, DC, USA, 2009; pp. 1-6.

130. GIZ. Rural Development and Adaptation to Climate Change: What Do We Know? Unique Forestry and Land Use Gmbh: Freiburg im Breisgau, Germany, 2013; Volume 3, pp. 1-91.

(C) 2018 by the authors. Licensee MDPI, Basel, Switzerland. This article is an open access article distributed under the terms and conditions of the Creative Commons Attribution (CC BY) license (http:/ / creativecommons.org/licenses/by/4.0/). 